\title{
Discussing surface crack structures in the Schorfheide region, NE Germany
}

\author{
Maximilian Krambach, Eric Runge, Ole Toelle
}

\begin{abstract}
Addresses of authors: Maximilian Krambach, Iburger Straße 45, 49082 Osnabrück, maximilian.krambach@posteo.de; Eric Runge, Samoastraße 13, 13353 Berlin, eric.runge@fu-berlin.de; Ole Toelle, Samoastraße 13, 13353 Berlin, ole.toelle@fu-berlin.de
\end{abstract}

Keywords: $\quad$ Geomorphology, northern Brandenburg, digital elevation modelling, airborne LiDAR, Salt Tectonic, Late Glacial, Laacher Tephra

\section{Introduction}

As a region characterized by intense glacial influence during the quaternary glaciations, the north-eastern part of Germany has a long geomorphologic research tradition. However, the chronology of ice-sheet dynamics and the interpretation of its related landforms is still a matter of discussion. The development of modern remote sensing technology provides new insights into, e.g., small scale landforms and enables a reassessment of landscape forming processes. Morphologic indications of local ice-ad- vances southward of the Pomeranian $\left(\mathrm{W}_{2}\right)$ ice-marginal position (IMP) during the $\mathrm{W}_{2}$-phase are still up to debate (Снговок \& Nitz 1987). The analysis of a high-resolution LiDAR (light detection and ranging) DEM (digital elevation model) revealed a multitude of east-west striking, curved negative landforms in the Schorfheide region. Situated $7-8 \mathrm{~km}$ in the foreland of the $\mathrm{W}_{2}$ IMP, the landforms' formation was expected to be directly connected to glacial morphodynamics. This study aims to describe the investigated landscape feature and to evaluate several explanatory approaches.

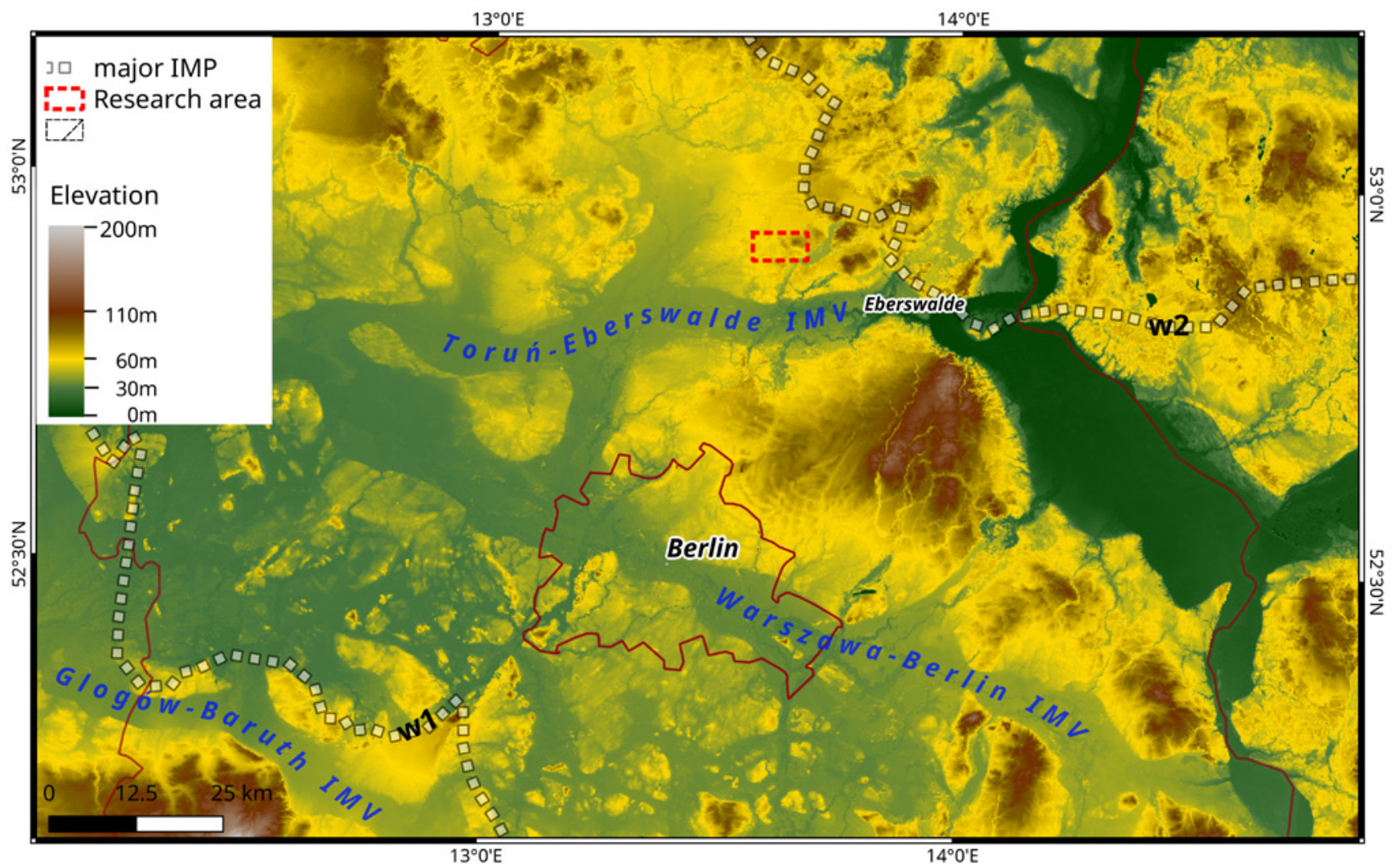

Fig. 1: Overview map of the young morainic landscape around Berlin. Data: SRTM (JARVIS et al. 2008), IMPs and IMVs according to LIEDTKE (1981). Abb. 1: Übersichtskarte fungmoränenlandschaft um Berlin. Datengrundlage: SRTM (JARVIS et al. 2008), Eisrandlagen und Urstromtäler nach LIEDTKE (1981). 


\section{Setting}

Located about $30 \mathrm{~km}$ to the north of Berlin, the Schorfheide region represents a part of the north-east German young morainic landscape (see fig. 1). Therefore, it was influenced by multiple glaciations during the Pleistocene, e.g. the Saalian and the Weichselian. During the Brandenburg Phase $\left(\mathrm{W}_{1 \mathrm{~B}}\right)$ the Scandinavian Ice Shield covered this area, whereas the $\mathrm{W}_{2}$ ice-advance is not believed to have reached the location (LiEDTKE 1981). Nevertheless, Pomeranian $\left(\mathrm{W}_{2}\right)$ sandur sediments cover large parts of the Schorfheide, later prominently reformed by aeolian transport, resulting in dune formation. The main Pomeranian terminal moraines are located to the northeast of the Schorfheide. The Torun-Eberswalde ice marginal valley (IMV) marks the southern border.

Our area of interest is located at the southeastern margin of the Schorfheide, and is divided into two major landscape units. The west is a more-or-less flat plain of glaciofluvial sands, featured by several oval depressions. The area shows two major lakes, namely Großer Pinnowsee and Kleiner Pinnowsee, as well as several bogs. The eastern part is a more elevated area, separated by a steep slope of up to $20 \mathrm{~m}$, marked by a distinct change in sediments, towards a variety of coarser sands, traces of glacial till and boulders. This eastern part is modified by fluvial processes, which can be separated into two generations. A first system discharging in eastern direction, towards the presentday Werbellinsee, has left broad valleys with banks of up to $15 \mathrm{~m}$ level difference. The valley beds, however, are not continuous anymore, but split up and possibly displaced by the landforms in question. A second system, less prominent in elevation, but clearly identifiable due to banks and branching, has a discharge direction to the southwest, to- wards the Meelake bog. It is dissected and has no continuous longitudinal profile anymore.

\section{Methods and material}

Airborne LiDAR data were acquired from the Landesvermessung und Geobasisinformation Brandenburg (LGB) with a resolution of $10 \mathrm{~m}$ for the research area and $1 \mathrm{~m}$ for selected sites. Based on these data, a DEM at $10 \mathrm{~m}$ resolution was created. The characterization of the morphostratigraphic setting and the spatial expansion of these landforms was done manually. Contrast enhancement was used to generate a better overview of the study site while clarifying the landform structures. Additional data and interpretations were obtained by analysis of historical maps (e.g. geological survey, BERENDT 1894; Schmettau maps 1767-1787, LGB 2016 \& Lithofazieskarten Quartär, CEPEK, Hartwich \& Lohde 1980, 1982). Furthermore, a first field survey was done.

\section{Results}

There are at least 20 elongated, curved negative landforms with a length ranging from $2 \mathrm{~km}$ to $5 \mathrm{~km}$ and a maximum width of $150 \mathrm{~m}$ (see fig. 2). They cut sharply into the surrounding landscape, reaching down $1 \mathrm{~m}$ to $15 \mathrm{~m}$. Subsequently, the landforms in question will be mentioned as "cracks", based on their visual appearance. According to geological maps (BERENDT 1891, 1894) and field observations, peat-formation is a prominent factor, especially in lower positions. Therefore, the actual depth remains unknown due to partial secondary infills. There is a tendency of inclination from west to east, however, this tendency only mirrors the general landscape, and is not continuous

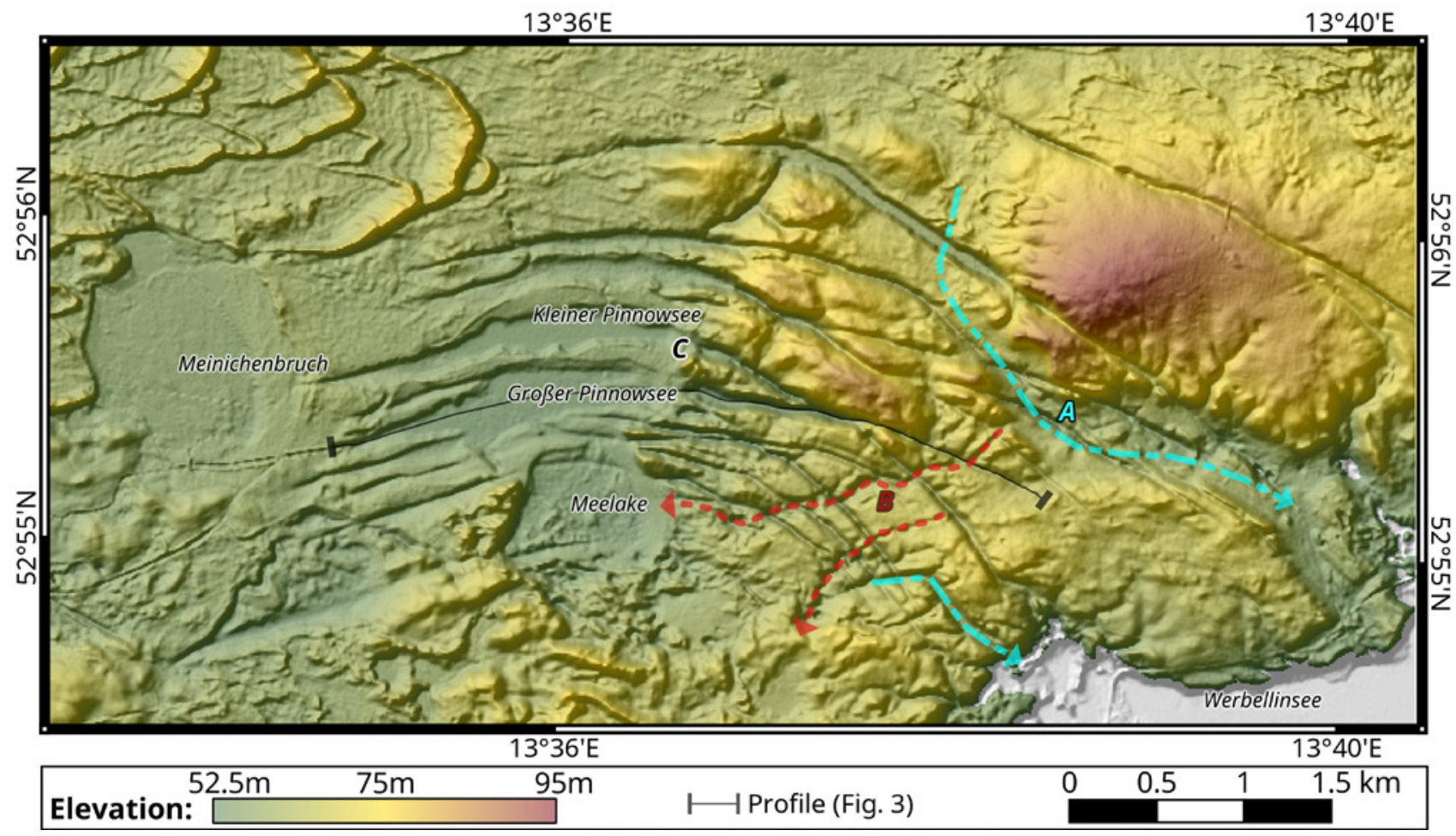

Fig. 2: Research Area (hillshading 20 times exaggerated) with marked fluvial features. Data: LiDAR DEM 10m (LGB).

Abb. 2: Untersuchungsgebiet (20-fach überhöhte Schummerung) mit markierten fluvialen Strukturen. Datengrundlage: LiDAR DEM 10m (LGB). 


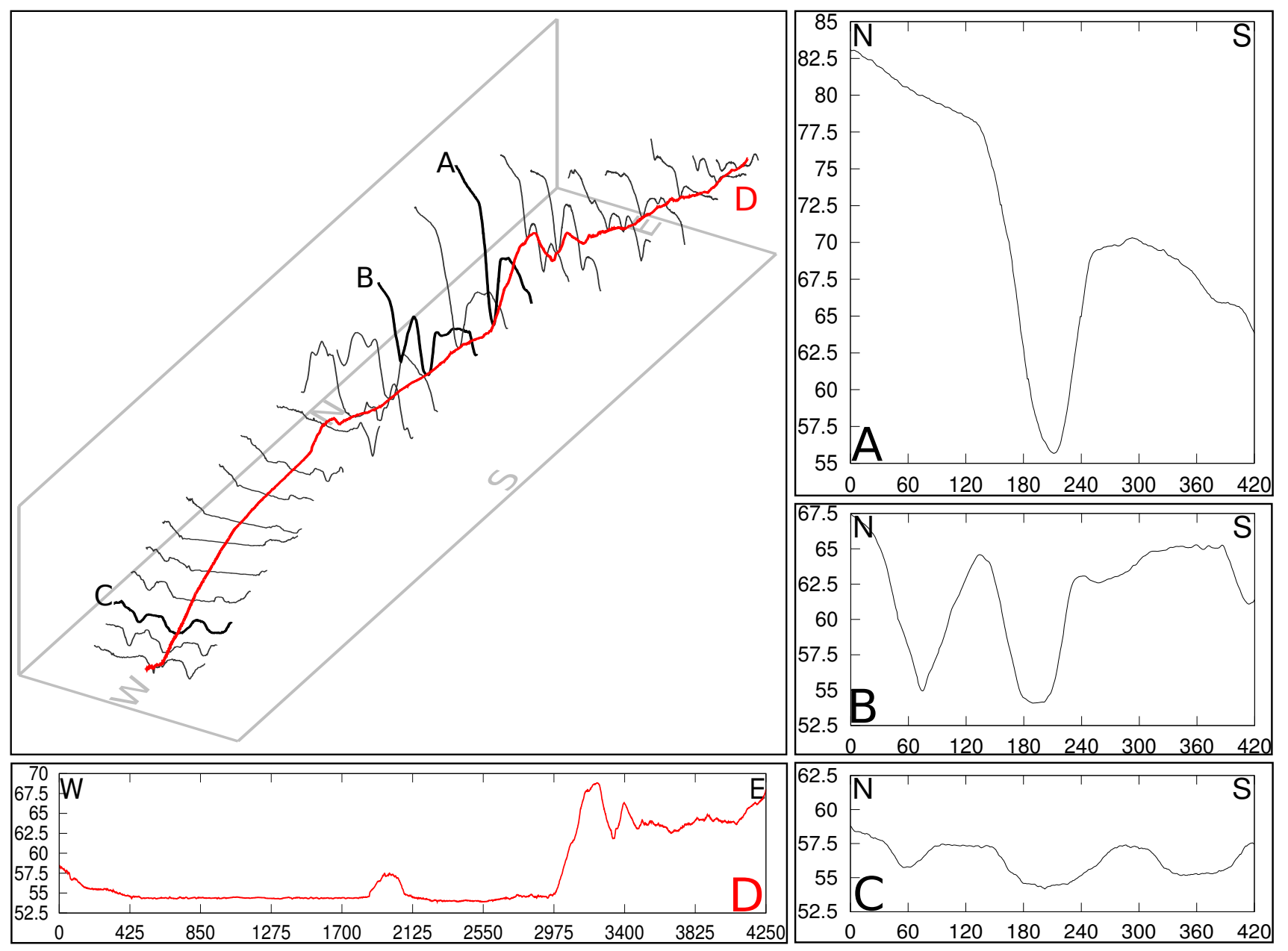

Fig. 3: Profiles of a selected landform at different positions. Red: Longitudinal profile. Position of the landform see Fig. 2.

Abb. 3: Profile einer ausgewählten Form an verschiedenen Stellen. Rot: Längsprofil. Lage der Form, siehe Abb. 2.

(see fig. 3). Reaching their eastern and western ends, the cracks are pointed upwards the slope, without any visible continuation to other landscape features. The transverse profiles show relatively flat bottoms, while the slopes are steep and disturbed by slides.

At least two distinguishable classes of cracks are visible, differing in depth of incision and in orientation related to the identified landscape units. While one half of the landforms show a southeastern orientation, the other half strikes towards east-southeast. In the western part, all landforms are roughly parallel. Due to the differences in the orientations, there are at least seven intersections, cross-cutting into each other, the ESE oriented forms being deeper than the SE oriented ones.

The most prominent commonality of these forms is that they cut into every other geomorphic feature visible in varying incision intensity. From the LiDAR-data it can be seen that even in the Meelake there is up to $1.5 \mathrm{~m}$ of level difference, outlining the continuation of such a crack.

\section{Discussion}

A first genetic interpretation of the presented landforms was done by BERENDT (1891). He interpreted them as valleys formed by a fluvial discharge from the Werbellinsee to the west, finding a continuation in a tunnel valley west of
Groß Schönebeck. This interpretation represents the state of the art until today. However, there is a gap of about $8 \mathrm{~km}$, a sudden ending of the landforms, and the height profile is not conform with this flow direction, not regionally, and less so locally. Also, the level differences and intersections between the cracks do not support a fluvial regime. LiedTKe (1956/57) considers the Großer and Kleiner Pinnowsee basins as dead-ice depressions, without discussing the regarded landforms in general. Both lakes are visibly integrated into the landforms, therefore it can be assumed that the lake development is a consequence of the cracks' genesis. Due to the extremely elongated shape of the depressions, an involvement of dead-ice decay seems implausible. Although melting of incorporated ice bodies in proglacial compressed material is conceivable, this approach cannot be supported as the cracks show an oppositional bending to the ice-margin. Regarding their orientation, other deformation processes related to proglacial tensions like glacial forebulge, can widely be excluded. Subglacial abrasion by large basal boulders should also be discarded, as they should still be found around the research site, especially in view of their required size.

Similar shaped landforms are described in southern Brandenburg by Kupetz, Kupetz \& RAscher (2004), known as the Muskauer Faltenbogen. Here, the formation is due to compression of proglacial material, including Tertiary lig- 
nite beds. Once exposed to Oxygen, weathering triggers a decrease in volume of these layers and subsequently to a deepening of surface. As no presence of near surface Tertiary material in our research area is mentioned in literature (CEPeK, Hartwich \& Lohde 1980, 1982), this approach can widely be excluded.

To set up a chronology of the formation, the work of Timmermann (1992) in the Meelake resulted in an important age mark. About 90 sites were drilled down to the mineral base of the bog in two south-north and one west-east transects. The N-S cross section clearly shows two of these negative landforms at the bottom of the Meelake, which later became visible on surface due to volume loss of the peats. Additionally, in about a third of the cores, Laacher See Tephra (12.9 ka BP) was found covering a layer of limnetic sediments (Timmermann 1992). Thus, it can be presumed that the landforms already existed at $12.9 \mathrm{ka}$ and were filled by water, if the Laacher See Tephra findings can be confirmed. Regarding the location of the site in the foreland of the $\mathrm{W}_{2}$ IMP, we assume, that the cracks are younger than the decay of the $\mathrm{W}_{1 \mathrm{~B}}$ glacier, and even younger as the $\mathrm{W}_{2}$ IMP ( 20 ka; Lüthgens, Böse \& Preusser 2011), as they cut into an outwash plain of Pomeranian $\left(\mathrm{W}_{2}\right)$ glaciofluvial deposits. This places the time frame of the formation into the late glacial, between $20 \mathrm{ka}$ and 12,9 ka, excluding a Holocene genesis.

Beside glacial or fluvial landscape forming processes, it should be taken into consideration that the North German Basin (NGB) is a region, which is influenced by neotectonic activity. Prominent factors are crustal movements in consequence of post-glacial isostatic rebound, as well as the formation of salinar structures, due to uplift of the Permian Zechstein rock (STAckeBRANDT 2005). A seismic survey of the surrounding region of Groß Schoenebeck, is given by Ollinger et al. (2010). It clearly shows a bulge of Permian deposits broadly underneath our research area, lifting-up the covering layers and reaching the Cenozoic base (Ollinger et al. 2010: Fig. 1). Though the influence on Quaternary sediments is not visible, a dependence between the salt tectonic activity and the current geomorphologic setting is plausible.

\section{Preliminary Chronology}

Here we present a first, preliminary chronology for the landscape elements of the study site:

The Scandinavian Ice Shield covered the area during the Brandenburg (W1) phase. No explicit tills of this phase have been identified, but especially the eastern part of the study site is rich in reworked, unsorted material and boulders. Direct traces of glacial covering are two, possibly three large kettle holes, which are regarded as relicts of former dead ice blocks that have been preserved after the main glacier decay (Meelake, Meinichenbruch).

Following the decay of the W1 ice sheet, glaciofluvial activities played a major role in landscape development. Westwards, the surface is almost bereft of tills and boulders, showing only glaciofluvial sediments and, locally, peats. Assuming a prior ice cover of the entire area during the Brandenburg phase, and considering the elevated eastern area, we assume that the deposited tills in the west have been washed out rather than covered. There is, however, no indication of a south- or southwest bound glaciofluvial system to be found. Here a development connected to the genetically hardly researched area of the Schorfheide itself can be considered.

The eastern part has clear fluvial traces, which are highlighted in Fig. 2. A first discharge (A) formed a broad valley with up to $500 \mathrm{~m}$ width and steep banks of more than $10 \mathrm{~m}$, originating at an unknown location north of the research area and flowing towards the Werbellinsee with supposed lake-level of about $55 \mathrm{~m}$ (12 m higher than today).

A second fluvial system (B) flowing to the west is far less extensive, but clearly distinguishable by its branching, meandering and the incision into the plateau. This system ends in kettle holes. This may point to a relative dating opportunity, as the existence of the kettle holes is determined by the meltdown of dead ice blocks.

The presented landforms cut through either fluvial systems and thus are of a younger age. Additionally, the beds of the large river valley (A) are inclined in various directions, and the height profile of the fluvial system (B) is not continuous anymore. Thus, a postfluvial dissection of the area can be presumed. A detailled mapping of those dissections may help to determine their nature. The postfeature development is not connected to any major fluvial activity anymore. The landforms themselves show a variety of slides, infills, peat development and groundwatersustained lakes. As the groundwater table of the area is highly variable, highly visible paleoshorelines have developed (C), but without connection to the features in question. Also, the occurrence of Laacher See tephra in peats inside the forms may place the form development before the Holocene.

\section{Perspectives}

Due to the research sites' diverse sedimentation dynamics, new detailed mapping of sediments could help update and reinterpret the 19th century geological survey.

Further dating of these forms may help to determine proglacial and periglacial dynamics. There is currently no known sediment that could be ascribed as being deposited during the formation of the curvilinear forms. Thus, dating will first focus on the center of these forms, where peat layers of up to several meters are to be expected. Another possible dating approach could include the search for paleosoils in non-peaty areas, such as the Finowboden, a paleosoil ascribed to the Allerød in this region. Radiocarbon dating of basal peat layers inside the forms may give another age marker.

For further genetic interpretation, a correlation of the two slopes of such a form will be attempted. If tectonic influences are assumed, possibly even a tilting of sediments can be expected. Both approaches have their difficulties due to the chaotic patterns of the sediments and sedimentation processes.

Attention will be given to other similar landforms in the region, such as Kuhzer See near Boitzenburg, about 30km further northwards. A detailed survey of other Late Pleistocene regions, with a LiDAR DEM of at least $10 \mathrm{~m}$ resolution or better, could help understand if the forms can be 
correlated with salinar features, other subsurface conditions, or with glacial dynamics.

\section{Acknowledgements}

We would like to greatly thank Prof. Dr. Margot Böse and Jacob Hardt, M.Sc. for their professional supervision and valuable advises.

\section{Literature}

Berendt, G. (1891): Groß Schönebeck, Gradabteilung 45, Nr. 2. - Geologische Karte von Preußen und benachbarten Bundesstaaten. 1:25.000.

Berendt, G. (1894): Blatt Gross-Schönebeck, Gradabteilung 45, Nr. 2 (3047). - Erläuterungen zur geologischen Specialkarte von Preußen und den Thüringischen Staaten; Berlin.

Cepek, A. G., Hartwich, R. \& Lohde, H. (1980): Lithofazieskarten Quartär - Blatt Zehdenik (1867). 1:50.000.

Cepek, A. G., Hartwich, R. \& Lohde, H. (1982): Lithofazieskarten Quartär - Blatt Eberswalde (1868). 1:50.000.

Сняовок, S. ひ Nitz, B. (1987): Die Entwicklung des Gewässernetzes der Oberen Finow vom Blankenberg-Interstadial bis heute. - Wissenschaftliche Zeitschrift der Ernst-Moritz-Arndt-Universität Greifswald, Mathematisch-naturwissenschaftliche Reihe, 36 (2-3): 20-25.

Jarvis, A., Reuter, H. I., Nelson, A. \& Guevara, E. (2008): Hole-filled Seamless SRTM Data V4. - International Centre for Tropical Agriculture (CIAT), (available from http:// srtm.csi.cgiar.org/)
Kupetz, A., Kupetz, M. \& Rascher, J. (2004): Der Muskauer Faltenbogen ein geologisches Phänomen. Grundlage einer 130jährigen standortgebundenen Wirtschaftsentwicklung. - Geopark in Brandenburg, Sachsen und der Wojewodschaft Lebuser Land. - 35 S.; Freiberg (GGW, Arbeitskreis Geoparke)

LGB (LANDESVERMESSUNG UND GEOBASISINFORMATION BRANDENBURG) (2016): Brandenburgviewer. - http://bb-viewer.geobasis-bb.de/ $(10.09 .2016)$

LiedTKe, H. (1956): Beiträge zur geomorphologischen Entwicklung des Thorn-Eberswalder Urstromtales zwischen Oder und Havel. - Wissenschaftliche Zeitschrift der Humboldt-Universität Berlin, Mathematisch-naturwissenschaftliche Reihe, 6: 3-49.

LiedtKe, H. (1981): Die nordischen Vereisungen in Mitteleuropa. - Forschung zur deutschen Landeskunde, 204-307; Trier (Zentralausschuss für deutsche Landeskunde).

Lüthgens, C., Böse, M. $\mho$ Preusser, F. (2011): Age of the Pomeranian ice marginal position in north-eastern Germany determined by Optically Stimulated Luminescence (OSL) dating of glaciofluvial sediments. Boreas, 40: 598-615.

Ollinger, D., Baujard, C., Kohl, T. \& Moeck, I. (2010): Distribution of thermal conductivities in the Groß Schönebeck (Germany) test site based on 3D inversion of deep borehole data. - Geothermics, 39: 46-58.

STACKEBRANDT, W. (2005): Neotektonische Aktivitätsgebiete in Brandenburg (Norddeutschland). - Brandenburger geowissenschaftliche Beiträge, $12,1 / 2: 165-172$.

Timmermann, T. (1992): Vegetationskundliche und stratigraphische Untersuchungen in der Meelake (Nordostbrandenburg). - Diplomarbeit am Fachbereich Biologie, Freie Universität Berlin (unpublished). 